\section{Nonprofit Organizations from the Perspective of Organizational Development and Their Influence on Professionalization}

\author{
Katalin Dobrai \\ University of Pecs, Faculty of Business and Management, \\ Department of Leadership and Organizational Sciences, Hungary \\ dobrai@ktk.pte.hu

\section{Ferenc Farkas} \\ University of Pecs, Faculty of Business and Management, \\ Department of Leadership and Organizational Sciences, Hungary \\ farkas@ktk.pte.hu
}

\begin{abstract}
The aim of this paper is to give an overview of the phenomenon of professionalization that is observable in organizations from the nonprofit sector. Empirical research was conducted among Hungarian nonprofit organizations, and the data were collected within the framework of a country-wide survey. Through the analysis of the research results, the paper provides deeper insights into knowledge about professionalization trends in the nonprofit sector. It proves that organizational development positively impacts nonprofit organizations' improvement of their professionalization level and the members of these organizations.
\end{abstract}

Keywords: organizational development, nonprofit organizations, professionalization, learning, knowledge

\section{Introduction}

The purpose of this paper is to provide an overview of special issues related to the growing professionalization of nonprofit organizations from both theoretical and practical perspectives. In recent years, new dilemmas have arisen for those involved in the nonprofit sector. These dilemmas regard knowledge processes such as learning and development of individuals working for nonprofit organizations (NPOs) as well as organizational development (OD) and the importance of professionalization for individuals and organizations.

Taking these circumstances into consideration, this article focuses on the relationship between the development of skills and the growing professionalization of their activities. With the participation of Hungarian nonprofit organizations, a large sample survey of Hungarian nonprofit organizations provided the basis for the empirical evidence. A general decline in the number of organizations during the last four years (Statisztikai Tükör, 2014) has drawn the authors' attention to the fact that sustainable existence of the organizations of the nonprofit sector to a large extent depends on their development.
ORIGINAL SCIENTIFIC PAPER

RECEIVED: NOVEMBER 2015

REVISED: FEBRUARY 2016

ACCEPTED: APRIL 2016

DOI: 10.1515/ngoe-2016-0009

UDK: 334.72

JEL: L30, 015

Citation: Dobrai, K., \& Farkas, F. (2016). Nonprofit Organizations from the Perspective of Organizational Development and Their Influence on Professionalization. Naše gospodarstvo/ Our Economy, 62(2), 25-32. DOI: 10.1515/ngoe-2016-0009

\section{NG OE}

NAŠE GOSPODARSTVO OUR ECONOMY

\begin{tabular}{l|l|l} 
Vol. 62 & No. 2 & 2016 \\
\hline
\end{tabular}

pp. $25-32$ 
The paper consists of two parts. The first part includes desk research in which we utilized papers discussing the professionalization of NPOs that were published mainly in the last decade. The second part contains a detailed research methodology along with analysis and discussion of the empirical research. The paper concludes with lessons learned from the research, limitations of the research, and suggestions for further research ideas.

\section{Theoretical Framework}

In this chapter, we briefly clarify the basic terms and phenomena relevant for the empirical research.

\subsection{Nonprofit organizations and challenges}

Different terms are used worldwide for organizations in the nonprofit sector (non-governmental, voluntary, etc.), and the terms themselves are used in various meanings. For this reason, it is necessary to explain our understanding of this term. We accept Salamon and Anheier's (1992) definition according to which nonprofit organizations are entities that:

- $\quad$ are institutionalized and have regularity in their activities;

- $\quad$ are private and independent from the government, even if they receive support from the government;

- do not distribute profits to their owners or leaders, but reinvest their surplus earnings into the objectives of the organizations;

- $\quad$ are not controlled by other entities from outside the organization; and

- provide voluntary membership or participation in the activities.

However, these principles are often are compromised in practice in many countries.

The changing environment makes daily operations for nonprofit entities increasingly difficult. Some challenges include the emergence of the so-called knowledge-intensive business services (Dobrai \& Farkas, 2008), competition from other sectors and from organizations in the nonprofit sector, and more rigorous regulations. Meeting these challenges involves making changes in nonprofit organization, structure, leadership and organizational processes (Epstein \& McFarlen, 2011). Performance is more essential than ever; thus, fulfilling commitments is challenging for the NPOs. NPOs must learn constantly so that they acquire knowledge from business sector companies (Chen \& Graddy, 2010; Kreutzer, 2009). By precisely defining their goals, they increase the likelihood of success in the accomplishment of their mission (Bradach, Tierney, \& Stone, 2008). Acquiring new and specialized knowledge in other fields also enables them to use models and solutions to implement methods of the business sector for long-term existence, better performance, and sustainable success (Al-Tabbaa, Leach, \& March, 2014). These changes found their way into the nonprofit sector from the business sector through the public sector, where methods of new public management were introduced. This led to the adoption of management practices of for-profit organizations (Lewis, 2001; Roberts, Jones, \& Fröhling, 2005).

\subsection{Professionalization in nonprofit organizations}

\subsubsection{The term "professionalization"}

The terms professionalization and professionalism have been the topic of continuous discussions. In numerous publications, Evetts has provided a very detailed and critical analysis of the sociological aspects of professionalism as well as its changes during the last decade to the present (Evetts, 2011; Maister, 2003).

Professionalization in NPOs can be understood as the implementation of business strategies and the use of methods and tools to help entities become market oriented (Mannsky \& Siebart, 2010). This process is characterized by the usage of tools and methods transferred into the nonprofit from the for-profit sector (Alfirević, Pavičić, \& Najev Čačija, 2014). This requires implementing strategic thinking into these organizations (Clark, 2012) and enabling them to perform well in special areas not focused on earlier, such as marketing (Chad, Kyriazis, \& Motion, 2014) or organizational performance (Alfirević et al., 2014). Publications reveal different concepts of professionalization, including organizational, occupational, and managerial factors (Evetts, 2011; Salamon, 2012).

Professionalization from the perspective of organizational sciences has become a current topic with respect to nonprofit organizations both in countries where NPOs have long existed and in the post-socialist countries where the sector's professionalization level is generally low (Rakar \& Kolarič, 2010). However, efforts have already addressed a large variety of country-specific questions (Alfirević et al. 2014; Čada \& Ptačková, 2014; Dill, 2014; Dill, Zrinščak, \& Coury, 2012; Korolczuck, 2014; Strečansky \& Stoláriková, 2012; Rakar et al., 2011).

Practice-oriented publications, such as those by Callanan, Gardner, Mendonca, and Scott (2014), suggest professional solutions for eliminating deficiencies in most leadership fields and activities. In addition, cultivating and staffing talent is 
attracting more attention now as a way to professionalize performance (Green \& Hauser, 2012; Neff \& Randal, 2011).

Based on the different concepts of professionalization and professionalism discussed and approaching them from the perspective of organizational sciences, we formulated our own definition that we found to be applicable for our empirical research. Hence, we understand professionalization as the process of becoming professional (i.e., developing a high level of professionalism). This involves not being an amateur anymore, showing expertise, skillfully executing organizational tasks, and providing superior services both internally and externally.

\subsubsection{Professionalization practices in the sector}

It is increasingly characteristic of the sector that, along with the traditional nonprofit organizations (associations and foundations), new legal and hybrid forms are emerging. Hybrid organizations possess characteristics of more than one sector (Billis, 2010; Davie, 2011; Strečansky \& Stoláriková, 2012) and systematically integrate the civil society and markets (Jäger \& Schröer, 2014). They use governance and operational methods, employ techniques of different organizational types, and are characterized by an improved business mindset. Their emergence is a sign of the dynamism and resilience of the sector's organizations (Salamon, 2012) that offer new solutions and opportunities, such as accessing social networks and other formalized structures, while bringing professionalized knowledge into the organizations. Dynamism and resilience are phenomena that accompany the implementation of different governance methods and techniques (Wellens \& Jegers, 2013). In addition, various intra-and inter-sector cooperative efforts contribute to improved organizational learning in the nonprofit sector as well as its becoming more effective (Al-Tabbaa et al., 2014; Chen \& Graddy, 2010; Cousins, Goh, Elliott, Aubry, \& Gilbert, 2014).

\subsubsection{Organizational development (OD)}

By narrowing the tools of professionalization, we now concentrate our attention on OD as a relevant component of our empirical research. Although a variety of definitions of OD are accepted and used by organizations, some common elements can be identified, as can be seen in the following brief overview.

Raia (1972, p. 13) sees the contribution of OD in its features in that it "focuses on innovation and planned change in organizations.” Its outcome is an increased body of knowledge. According to one popular definition, organizational development is "the system-wide application and transfer of behavioral science knowledge to the planned development, improvement and reinforcement of the strategies, structures and processes that lead to organizational effectiveness" (Cummings \& Worley, 2008, p. 752). Jackson (2006, p. 33) also stressed that OD is a collaborative process to improve organizational effectiveness.

OD is also viewed as a means of professionalization and capacity building. OD is a process that focuses on the organization and not the individual, although it provides the individual with an opportunity to learn, acquire, and develop new knowledge. In the nonprofit sector, the choice of how to develop different capacities depends on stakeholders' interests as they have different preferences and different reasons to support organizational development initiatives (Millesen, Carman, \& Bies, 2010). OD practitioners play a central role in the OD process. They are consultants who work as facilitators together with nonprofits in fields where OD is necessary-namely, in various areas of interventions in the nonprofit organizations such as people carrying out the projects, staff and organization leaders, or even donors (Tschirhart \& Bielefeld, 2012).

OD practitioners provide knowledge-intensive services (Dobrai \& Farkas, 2008) that lead to a joint learning process and the co-production of new knowledge. Wirtenberg and her colleagues (2007) found that OD experts can and should contribute to the development of nonprofit organizations in areas of urgency by working together with the leaders of nonprofits, transferring knowledge to them, and presenting a high level of flexibility.

For our empirical research, we built upon the previously mentioned features of OD. We view this management tool as a top-down effort that involves the whole organization and aims to increase the efficiency and lifecycle of an organization by taking structured actions. Thus, in conclusion to this brief overview, we can say that the implementation and usage of management tools and techniques, the introduction of new and better solutions, networking, cooperation and special processes such as OD are critical to improving the professionalization level of an organization.

\section{Empirical Research}

The following sections of the paper provide a brief summary and analysis of the empirical research.

\subsection{Hypotheses}

This article summarizes the findings that answer the following hypotheses: 
H1. A significant difference can be observed in the level of professionalism between the organizations that have already participated in OD programs and those organizations that have not taken part in such programs.

H2. Organizational development programs help the professionalization of nonprofit organizations.

H3. There is a connection between the perceived professionalization level of the respondent and that of his/her perception of the organizational level of professionalization.

H4. The differences perceived in the personal and organizational professionalism show a close correlation.

\subsection{Methodology}

In order to determine whether organizational development a suitable tool for promoting and enhancing the professionalization of nonprofit organizations, we used various methods during the different phases of the research (Table 1).

The empirical research started in 2011-2012 with a pilot project that included two counties in Hungary (there are 19 regional units called counties in Hungary). An online questionnaire was sent to 58 participants of an organizational development program at the House of Civil Communities in Pécs and was returned by 33 organizations. In the next phase, semi-structured interviews were conducted with representatives of 38 organizations, most of whom participated in the online survey. In the third phase (i.e., 2013), a large sample survey took place that used the experiences of the first two phases and the database of the Central Statistical Bureau of Hungary. We also conducted 41 additional interviews in the last research phase with organizations from different regions of the country.
For the country-wide survey, 18,000 questionnaires were sent to organizations via e-mail; 841 questionnaires were returned, representing each of the official activities listed by the Hungarian Statistical Office. The returned questionnaires met the requirements of representativeness regarding the location of the organizations and showed the approximate relationship between the two basic legal forms (associations and foundations).

\section{Results and Discussion}

\subsection{Findings}

We can make the following general statements about the participating organizations and the people who filled out the questionnaire for those organizations:

There is a medium-strength positive relationship between the age of the organization and the number of full-time employees, which implies that older organizations have a higher number of full-time employees (Pearson correlation: $0.250^{* *}$, significant at the 0.01 level, 2-tailed).

- There is a positive relationship between the age of the organizations and the number of members, suggesting long-term development and the opportunity for performance improvement (Pearson correlation: 0.297**, significant at the 0.01 level, 2-tailed).

- Both findings have very important implications for the performance of the organizations in the sector. It is well known that many organizations do not have any paid employees for obvious reasons.

- The analysis of the relationship between personal and organizational professionalization (Table 2) shows that:

Table 1. Phases of the Research and Methods Applied

\begin{tabular}{lccc} 
Research Phases & Methods Used & $\begin{array}{c}\text { Number of Organizations } \\
\text { Involved }\end{array}$ & $\begin{array}{c}\text { Location of Organizations } \\
\text { Involved }\end{array}$ \\
\hline Phase 1 & questionnaire & 33 & 2 counties \\
\hline Phase 2 & interviews & 38 & 2 counties \\
\hline Phase 3 & questionnaire & 841 & country-wide \\
\hline Phase 4 & interviews & 41 & country-wide \\
\hline
\end{tabular}

Source: Authors' own data

Table 2. Participation in an OD Program, and the Perceived Level of Professionalization (7-Point Scale, Mean)

\begin{tabular}{lcc} 
Participation in OD Program & \multicolumn{2}{c}{ Evaluation of Professionalization (7-point scale) } \\
\hline \multirow{2}{*}{ Participated } & Individual & Organization \\
\cline { 2 - 3 } & 4.78 & 4.62 \\
\hline Did not participate & 3.60 & 3.41 \\
\hline
\end{tabular}

Source: Authors' own data 
- Respondents who previously participated in OD programs gave their own professionalization level an average score of 4.78 on a 7 -point scale and placed the professionalization level of their organization somewhat lower, with an average score of 4.62; and

- Respondents who had never participated in an OD program perceived the two professionalization levels as being much lower: 3.60 for the individual and 3.41 for the organization. (H1)

This result was also supported by a correlation analysis that pointed out a positive connection between participation in an OD program and the perceived professionalization level (H2)-namely:

- A medium-strength positive connection between participation in an OD program and the perceived level of personal professionalization (Cramer's V: 0.355; $p=0.000$, Pearson correlation: 0.493. Correlation is significant at the 0.01 level, 2-tailed); and

- A medium-strength positive connection between participation in an OD program and the perceived level of organizational professionalization (Pearson correlation: 0.575. Correlation is significant at the 0.01 level, 2-tailed).

The hypothesis was also accepted (Table 3) regarding the impact on satisfaction with the program by the program provider's origin. According to the research findings, how efficient participants find an OD program depends on the provider of the OD program. Although no significant difference exists between the averages of the three categories, those who had participated in an EU-supported OD program found that they had reached a high level of professionalism. Those least satisfied were the participants of domestic programs (H3).

If we look at the whole sample, we can say that, regarding the personal and organizational professionalization level (Table 4), for their own personalization level, respondents gave on average a score of 3.93 and scored their organization's professionalization level 3.75 on average. Skewing and kurtosis showed normal distribution in both cases. This difference implies that opportunities exist for further professionalization of the organizations if they utilize members' knowledge.

If we want to analyze the relationship between perceived level of personal professionalization and the field of activity of the represented organization by using the test of homogeneity of variances and ANOVA, we can state that, at the 5\% significance level, a connection exists between the two variables ( $p=0.017$ ). By using the same methods, we also find a relationship between the perceived level of organizational professionalism and the field of activity of the represented organization $(p=0.000)$.

The data from our research also show that the higher the perceived level of the personal professionalization, the higher the perceived level of organization professionalization (Pearson correlation: $0.753^{* *}$, Sig. (2-tailed) 0.000 , strong and positive relationship. [H4]).

Table 3. Provider of the OD program and the Perceived Level of Professionalization (7-Point Scale, Mean)

\begin{tabular}{lcc}
$\begin{array}{l}\text { Origin of the Organization Providing the } \\
\text { OD program }\end{array}$ & Level of Personal Professionalism & Level of Organizational Professionalism \\
\hline Hungary & 4.67 & 4.50 \\
\hline EU & 5.03 & 4.81 \\
\hline Foreign & 4.87 & 4.87 \\
\hline
\end{tabular}

Source: Authors’ own data

Table 4. Comparison of Perceived Level of Personal and Organizational Professionalization

\begin{tabular}{|c|c|c|}
\hline Characteristics & Personal & Organizational \\
\hline \multicolumn{3}{|c|}{ Professionalism } \\
\hline $\mathrm{N}$ & 776 & 774 \\
\hline Mean & 3.93 & 3.75 \\
\hline Std. deviation & 1.584 & 1.598 \\
\hline Mode & 5 & 3 \\
\hline Skewness & -.158 & -.699 \\
\hline Std. Error of Skewness & 0.88 & 0.88 \\
\hline Kurtosis & -.632 & -.763 \\
\hline Std. Error of Kurtosis & .175 & .176 \\
\hline
\end{tabular}

Source: Authors’ own data 
Observing the connection between the professionalization level of the organization and the age of the organization, we can conclude that those organizations that achieved the highest professionalization level (4.10) had been operating for 9 to 15 years whereas the lowest level was characteristic of organizations that had existed for 1 to 3 years (2.88). The difference between these values also supports our assumptions regarding the connection among age, development, and professionalism at both the individual and organizational levels.

\subsection{Limitations of present study and opportunities for future research}

As the survey results demonstrated, the OD programs helped people and organizations learn and improve their skills and knowledge and become more professional in their service. Hence, it is a good tendency not only to look at the targeted community that these organizations serve, but also take care of the organization. The finding that the OD programs and OD providers influence the subjective professionalization level of the individual can facilitate a better choice of OD program.

The research limitations are twofold. In some cases, although it was clear that there was a difference between the different categories, some tests to prove it with a more sophisticated method could not be carried out because the sample did not satisfy certain criteria of that method. The comparability of the results with research in other countries is limited as most papers address a diversity of topics related to country-specific problems of professionalization as mentioned in the theoretical part of the paper (Dill, 2014; Korolczuck, 2014; Strečansky \& Stoláriková, 2012). However, this also suggests the possibilities for further research to be expanded internationally based on the existing experiences and to be deepened and broadened.

\section{Conclusion}

Through an analysis of writings and examples from actual practice, this article has provided evidence of the fact that nonprofit organizations feel the importance of organizational development from the perspective of their sustainable existence. As the survey results demonstrated, OD programs help nonprofit organizations learn and improve their skills and knowledge and become more professional in their services.

The findings support our hypotheses that OD programs and OD providers influence the subjective professionalization level of the individual and of the organization and that a strong positive relationship exists between personal and organizational professionalism. The hypotheses were verified, and the answer to the research question is that organizational development is a suitable tool to promote and enhance the professionalization of nonprofit organizations.

However, our research should also be compared with research in other countries. Future research could be expanded internationally and Phase 4 interviews deeply analyzed.

This paper contributes to the knowledge of the professionalization in the nonprofit sector not only in Hungary, but also in other post-socialist countries. As a result, Western counterparts can also see the development of the sector in this region.

\section{References}

1. Alfirević, N., Pavičić, J., Najev Čačija, L. (2014). Performance of non-profit organizations: Empirical contrasts between privately and publicly funded Croatian humanitarian organizations. Economic Annals, LIX(8), 115-129. http://dx.doi.org/10.2298/EKA1400115A

2. Al-Tabbaa, O., Leach, D., \& March, J. (2014). Collaboration between nonprofit and business sectors: A framework to guide strategy development for nonprofit organizations. Voluntas, 25(3), 657-678. http://dx.doi.org/10.1007/s11266-013-9357-6

3. Billis, D. (2010). From welfare bureaucracies to welfare hybrids. In D. Billis (Ed.), Hybrid organizations and the third sector: Challenges for practice, theory and policy (pp. 3-24). London: Palgrave Macmillan.

4. Bradach, J. L., Tierney, T. J., \& Stone, N. (2008). Delivering on the promise of nonprofits. Harvard Business Review, December, 88-97.

5. Čada, K., \& Ptačková, K. (2014). Between clients and bureaucrats: An ambivalent position of NGOs in the social inclusion agenda in Czech statutory cities. Policy and Society, 129-139. http://dx.doi.org/10.1016/j.polsoc.2014.05.003

6. Callanan, L., Gardner, N., Mendonca, L., \& Scott, D. (2014). What social-sector leaders need to succeed. Insights and Publications, November, 1-10. Retrieved from http://www.mckinsey.com/insights/social_sector/what_social_sector_leaders_need_to_succeed

7. Chad, P., Kyriazis, E., \& Motion, J. (2014). Bringing marketing into non-profit organisations: A managerial nightmare! Australasian Marketing Journal, 22, 342-349. http://dx.doi.org/10.1016/j.ausmj.2014.09.003

8. Chen, B., \& Graddy, E. A. (2010). The effectiveness of nonprofit lead-organization networks for social service delivery. Nonprofit Management and Leadership, 20(4), 405-422. http://dx.doi.org/10.1002/nml.20002

9. Clark, W. (2012). Introducing strategic thinking into a non-profit organization to develop alternative income streams. Journal of Practical Consulting, 4(1), 32-42.

10. Cousins,J. B., Goh, S. C., Elliott, C.,Aubry, T., \& Gilbert, N. (2014). Government and voluntary sector differences in organizational capacity to do and use evaluation. Evaluation and Program Planning, 44(June), 1-13. http://dx.doi.org/10.1016/j.evalprogplan.2013.12.001 
11. Cummings, T. G., \& Worley, C. G. (2008). Organization development \& change. Mason, GA: South-Western Cengage Learning.

12. Davie, G. (2011). Social entrepreneurship. A call for collective action. OD Practitioner, 43(1), 17-23.

13. Dill, A. P. (2014). Health care and disability NGOs in Croatia: State relations, privatization, and professionalism in an emerging field. Voluntas, 25(5), 1192-1213. http://dx.doi.org/10.1007/s11266-014-9440-7

14. Dill, A. P., Zrinščak, S., \& Coury, J. M. (2012). Nonprofit leadership development in the post-socialist context: The case of Croatia. Administration in Social Work, 36(3), 314-341. http://dx.doi.org/10.1080/03643107.2011.602470

15. Dobrai, K., \& Farkas, F. (2008). Knowledge-based organizations: Examining knowledge processes in public-serving nonprofit organizations. International Journal of Knowledge, Culture and Change Management, 8(2), 9-22.

16. Epstein, M. J., \& McFarlan, F. W. (2011). Nonprofit vs. for-profit boards. Critical differences. Strategic Finance, March, 28-35.

17. Evetts, J. (2011). A new professionalism? Challenges and opportunities. Current Sociology, 59(4), 406-422. http://dx.doi. org/10.1177/0011392111402585

18. Green, A., \& Hauser, J. (2012). Managing to change the world. The nonprofit manager's guide to getting results. San Francisco: JosseyBass.

19. Jackson, J. C. (2006). Organization development. The human and social dynamics of organizational change. Lanham: University Press of America, Inc.

20. Jäger, U. P., \& Schröer, A. (2014). Integrated organizational identity: A definition of hybrid organizations and a research agenda. Voluntas, 25(5), 1281-1306. http://dx.doi.org/10.1007/s11266-013-9386-1

21. Korolczuk, E. (2014). Promoting civil society in contemporary Poland: Gendered results of institutional changes. Voluntas, 25(4), 949-967. http://dx.doi.org/10.1007/s11266-013-9388-z

22. Kreutzer, K. (2009). Nonprofit governance during organizational transition in voluntary associations. Nonprofit Management and Leadership, 20(1), 117-133. http://dx.doi.org/10.1002/nml.244

23. Lewis, D. (2001): The management of non-governmental development organizations. New York: Routledge. http://dx.doi. org/10.4324/9780203002162

24. Maister, D. (2003). Managing the professional service firm. London: Simon Schuster UK Ltd.

25. Mannsky, A., \& Siebart, P. (2010). Trends der Professionalisierung in Nonprofit-Organisationen. Frankfurt am Main: PWC. Retrieved from https://www.pwc.de/de_DE/de/offentliche-unternehmen/assets/Trends_der_Professionalisierung_in_Nonprofit-Organisationen.pdf

26. Millesen, J. L., Carman, J. G., \& Bies, A. L. (2010). Why engage? Understanding the incentive to build nonprofit capacity. Nonprofit Management and Leadership, 21(1), 5-20. http://dx.doi.org/10.1002/nml.20009

27. Neff, D. J., \& Randal, C. (2011). The future of nonprofits. Innovate and thrive in the digital age. Hoboken, NJ: John Wiley \& Sons, Inc. http://dx.doi.org/10.1002/9781118386781

28. Raia, A. P. (1972). Organizational development-Some issues and challenges. California Management Review, 14(4), 13-20. http:// dx.doi.org/10.2307/41164378

29. Rakar, T., \& Kolarič, Z. (2010). A szlovén non-profit szektor sajátos hely(zete) a posztszocialista országok között (Special position of the Slovenian non-profit sector among the post-socialist countries). Civil Szemle (Civil Review), 2, 75-87.

30. Rakar, T., Vrbica, S. Š., Deželan, T., Kolarič, Z., Črnak-Meglič, A., Nagode, M., \& Matoz Ravnik, A. (2011). CIVICUS Civil Society Index analytical country report for Slovenia, 2010. Towards maturity: challenges for Slovenian civil society. Ljubljana: Social Protection Institute of the Republic of Slovenia Retrieved from http://civicus.org/downloads/CSI/Slovenia.pdf

31. Roberts, S. M., Jones, J. P. III, \& Fröhling, O. (2005). NGOs and the globalization of managerialism: A research framework. World Development, 33(11), 1845-1864. http://dx.doi.org/10.1016/j.worlddev.2005.07.004

32. Salamon, L. M. (Ed.) (2012). The state of nonprofit America. Washington, DC: Brookings Institution Press.

33. Salamon, L. M., \& Anheier, H. K. (1992). In search of the nonprofit sector II: The problem of classification. Baltimore: The Johns Hopkins University Institute for Policy Studies.

34. Statisztikai Tükör (Statistical Mirror) (2014). A nonprofit szektor legfontosabb jellemzői, 2013 (The most important characteristics of the nonprofit sector, 2013). Statisztikai Tükör (Statistical Mirror), 142, 19.

35. Strečansky, B., \& Stoláriková, K. (2012). Social economy and social enterprises in Slovakia. Civil Szemle (Civil Review), 9(4), 87-100.

36. Tschirhart, M., \& Bielefeld, W. (2012). Managing nonprofit organizations. Hoboken, NJ: John Wiley \& Sons, Inc.

37. Wellens, L., \& Jegers, M. (2013). Effective governance in nonprofit organizations. A literature based multiple stakeholder approach. European Management Journal, 1-21.

38. Wirtenberg, J., Backer, T. E., Chang, W., Lannan, T., Applegate, B., Conway, M., ... \& Slepian, J. (2007). The future of organization development in the nonprofit sector. Organization Development Journal, 25(4), 179-195.

Acknowledgments: The authors are grateful to the Hungarian Scientific Research Fund project No. 101886 for supporting the research "Knowledge-based services_Professionalization of nonprofit organizations," analyzed in the paper. This paper is dedicated to the $650^{\text {th }}$ anniversary of the establishment of the University of Pécs, Hungary. 


\section{Authors}

Katalin Dobrai, Ph.D., is an associate professor at the Department of Leadership and Organizational Sciences of the Faculty of Business and Economics of the University of Pécs. Her teaching areas include leadership and organization, knowledge management, and human resource management. Her research focuses on knowledge management and organizational learning in knowledge-intensive businesses and nonprofit organizations. Postal address: 7622 Pecs, Rakoczi str. 80, Hungary; Phone: (36) 72/ 501599 ext. 23132, e-mail: dobrai@ktk.pte.hu

Ferenc Farkas, Ph.D., is a full professor at the Department of Leadership and Organizational Sciences of the Faculty of Business and Economics of the University of Pécs. His teaching areas include change management, organizational behavior, and leadership. His research interest focuses on nonprofit management and leadership as well as HRM. He has been the team leader of Hungarian and international projects, financed by the EU and the Hungarian government. Postal address: 7622 Pecs, Rakoczi str. 80, Hungary; Phone: (36) 72/ 501599 ext. 23130, e-mail: farkas@ktk.pte.hu

\section{Neprofitne organizacije z vidika organizacijskega razvoja in njegovega vpliva na profesionalizacijo}

\section{Izvleček}

Cilj tega članka je predstaviti fenomen, ki se imenuje profesionalizacija in ki ga je mogoče opaziti v organizacijah neprofitnega sektorja. Empirična analiza je bila izvedena v madžarskih neprofitnih organizacijah, podatki pa so bili pridobljeni v okviru deželne raziskave. Z analizo raziskovalnih izsledkov omogoča članek globlji vpogled v znanje o profesionalizacijskih trendih v neprofitnem sektorju. $\vee$ članku dokazujemo, da organizacijski razvoj pozitivno vpliva na izboljšanje ravni profesionalizacije $\checkmark$ neprofitnih organizacijah in pri njihovih članih.

Ključne besede: organizacijski razvoj, neprofitne organizacije, profesionalizacija, učenje, znanje 